\title{
EFFECT OF IN-OVO-INJECTION OF POTASSIUM IODIDE ON THYROID ACTIVITY AND SOME HEMATOLOGICAL AND BIOCHEMICAL INDICES OF BROILER CHICKS
}

\author{
Hassan Awad Albdrani \\ Abdullah F. Abdul-Majeed \\ Department of Animal Production / College of Agriculture and Forestry/ \\ University of Mosul / Iraq \\ dr.abdullah@uomosul.edu.iq
}

\begin{abstract}
The current study aimed to evaluate the effects of potassium iodide in-ovo injection on thyroid gland activity and some hematological and biochemical indices of broiler chicks. A total of four hundred seventy-seven fertilized broiler eggs (Ross 308) were randomly distributed into 3 groups (159 eggs/group), with 3 replicates (53 eggs/replicate). Eggs of $1^{\text {st }}$ group were considered as a negative control (not injected), the $2^{\text {nd }}$ group eggs were injected with $0.2 \mathrm{~mL}$ deionized water (positive control), whereas the $3^{\text {rd }}$ group eggs were injected into the allantoic sac, with $2 \mathrm{mg}$ potassium iodide/ egg in $0.2 \mathrm{~mL}$ volume, on the $10^{\text {th }}$ day of incubation. On hatch day, hatchability\%, embryonic mortality\%, chicks weight were measured, and hematological and biochemical tests were conducted. The weight of the hatched chicks from injected eggs with potassium iodide was significantly lower than that in negative control group $(\mathrm{P} \leq 0.05)$, moreover, a significant increase was recorded for hemoglobin, packed cell volume\%, lymphocytes\%, and thyroxine concentration as compared with the control group, meanwhile a significant decrease was recorded for the heterophils $\%, \mathrm{H} / \mathrm{L}$ ratio, cholesterol, triglycerides and triiodothyronine concentration as compared with the control group $(\mathrm{P} \leq 0.05)$. In conclusion, potassium iodide has an important impact on thyroid activity and reduces stress on the incubated eggs, as well as on some hematological indices of hatched chicks.

Keywords: In-ovo-injection, Potassium iodide, Thyroid, Thyroxine, Triiodothyronine.
\end{abstract}

Received: 19/7/2020, Accepted: 11/8/2020.

\section{INTRODUCTION}

Iodine is an essential and irreplaceable component of the bioprocesses for humans and animals (Saki et al., 2012), and it has an important physiological role in avian metabolic pathways (Eila et al., 2012), its deficiency leads to loss of appetite and reduces productivity performance, loss of feathers, retarded growth, puberty, sexual maturity, and delayed hatching (Behroozlak et al., 2020). Iodine can be added to ration and water in various forms: inorganic sodium and potassium salts (iodide or iodate), and the potassium iodide (KI) is a form of inorganic iodine that can be given to animals and humans (Ibrahim et al., 2015). Iodine is necessary for thyroid hormones biosynthesis, which regulates both anabolic and catabolic pathways of protein, fats, and carbohydrates (Eila et al., 2012).

*Part of M.Sc. thesis submitted by the first author. 
The avian thyroid gland is one of the first endocrine glands which develop in the chick embryo (McNabb, 2006), which is a small pair, dark red oval structures, located at the anterior-lateral side of the trachea at the thoracic inlet. The Thyroid gland secretes approximately $60 \%$ Thyroxine $\left(\mathrm{T}_{4}\right)$, and $40 \%$ Triiodothyronine $\left(\mathrm{T}_{3}\right)$ (the biologically more active form) (Schmidt and Reavill, 2008), and the amount of hormone production depends on the amount of iodine absorbed (Musa et al., 2008). Thyroid hormones are essential for embryonic development throughout the incubation period, the thyroxine increases from the $10^{\text {th }}$ day and reaches its maximum on the $20^{\text {th }}$ day of the incubation before pipping, while the $T_{3}$ level remains low until the $19^{\text {th }}$ day age of incubation, then rises (Alhassani, 2000).

In order to provide the embryos with iodine, and to study its effects on thyroid activity during the incubation period, in-ovo injection method was used. It's one of the distinctive methods which were used by many researchers to introduce various elements as a supplemented nutrients into the eggs (Peebles, 2018), whether probiotics (Ahmed and Manati, 2015), fatty acids (Schaal, 2008), vitamins (Bhanja et al., 2012) and amino acids (Bhanja et al., 2005) and the injection can be performed in the allantoic cavity, amniotic cavity, yolk sac, air cell, etc. (Roto et al., 2016).

Therefore, the objective of this study is to evaluate the effects of in-ovo injected potassium iodide on the embryonic thyroid gland activity during incubation, and it's a reflection on the hatchability\%, hatched chick's weight, embryonic mortality\%, also its effect on the serum thyroid hormones and some blood parameters of hatched chicks.

\section{MATERIALS AND METHODS}

A total of four hundred seventy-seven fertilized hatching eggs were collected from broiler breeders (Ross 308) by commercial Kosar company, Irbil / Iraq, then randomly distributed into 3 groups (159 eggs/group), with 3 replicates/group (53 eggs/replicate) at average weight 57 grams.

The eggs were incubated in an automatic Turkish-made incubator type Cimuka (800 eggs), and the incubating conditions (temperature, humidity, and egg turning times) were adjusted according to Randall and Bolla (2008), and Clauer (2009).

Eggs candling were performed on the $10^{\text {th }}$ day of the incubation in a dark biosafety cabinet to verify the fertilized eggs and the embryonic growth, and to identify and sterilize the injection area. The eggshell was punctured, then the potassium iodide solution was injected $(2 \mathrm{mg} / \mathrm{egg}$ in a volume of $0.2 \mathrm{ml})$ in the Allantoic sac by using an automatic medical syringe (gauge 30), taking into consideration does not injure the embryonic blood vessels. Finally, the injection area was closed by nail polish, and then the eggs were immediately returned to the incubator by placing the air cell up until hatching occurred. The experimental groups were as follows:

$1^{\text {st }}$ group (negative control): 159 fertilized eggs that were not injected with any substance.

$2^{\text {nd }}$ group (positive control): 159 fertilized eggs injected with deionized water $(0.2 \mathrm{ml} / \mathrm{egg})$, into the allantoic sac. 
$3^{\text {rd }}$ group (KI group): 159 fertilized eggs injected with potassium iodide solution (KI) in a dose of $2 \mathrm{mg} / \mathrm{egg}$ and in a volume of $0.2 \mathrm{ml} / \mathrm{egg}$, into the allantoic sac.

At the end of the incubation period (21 days), the hatchability\% and embryonic mortality\% were calculated, then each hatched chick weighted according to the study groups.

Six hatched chicks (on the day of hatching) were slaughtered from each group ( 2 chicks/ replicate/ group) and the blood samples were collected immediately in two types test tubes: $1^{\text {st }}$ tube with anticoagulant (EDTA) used for the blood picture to determine the hemoglobin concentration $(\mathrm{Hb})$, packed cell volume (PCV\%) as well as, differential leukocyte count (DLC), heterophil/ lymphocyte ratio, $2^{\text {nd }}$ tube without anticoagulant to separate the serum which preserved in the Eppendorf tubes at (-20oc) until performing the biochemical tests, which included: determination of serum glucose, total cholesterol, triglycerides, total protein, albumin, globulin using Biosystems kits (Spanish made). On the other hand, Triiodothyronine (T3), Thyroxine (T4) and Thyroid-stimulating hormone (TSH) concentration were all measured by the electrochemiluminescence immunoassay method using an COBAS e411 automated machine analyzer (Roche Company, Germany).

\section{Statistical analysis:}

Statistical analysis was performed using Statistical Analysis Statics program (Anonymous, 2008), and the collected data were analyzed using one-way analysis of variance, then Duncan's Multiple Range test (Duncan, 1955) was used to determine the differences between the means $(\mathrm{P} \leq 0.05)$, according to Steel and Tories (1960).

\section{RESULTS AND DISCUSSION}

The results observed in Table 1 shows that potassium iodide injection did not significantly affect hatchability\% and embryonic mortality\% in $\mathrm{T}_{3}$ group (KI group) compared with control group, these results did not agree with the results of Guo et al., (1991).

Data in Table 1 revealed a significant decrease in the hatched chick weight in the $\mathrm{T}_{3}$ group (eggs injected with KI) compared with the control group. This result was in agreement with Klein and Ojamaa (2001); Sainsbury and Zhang (2012) and Kim (2008) who reported that "In hyperthyroidism, the most evidence is an increased metabolic rate and weight loss". While no significant effects on chick weight were found by Behroozlak et al., (2020) and Schultz (2012). These results may be related to the effect of potassium iodide ovo-injection which increased thyroid gland activity during the incubation period, which was accompanied by an increased metabolic rate and chicks weight loss, the presence of a significant increase in the thyroxine level in $\mathrm{T}_{3}$ group (Table 5) compared with the control groups $\left(T_{1}\right.$ and $\left.T_{2}\right)$, Also sustain this effect Behroozlak et al., (2020) mentioned, that it may be due to higher body metabolism rate related to increased iodine retention and blood thyroxine level. 
Mesopotamia J. of Agric.

Vol. (48) No. (3) 2020
ISSN: 2224 - 9796 (Online)

ISSN: 1815 - 316 X (Print)

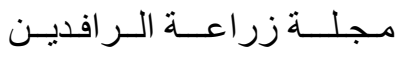

المجلد (48) العدد (3) 2020

Table (1): Effect of in-ovo injection of potassium iodide on hatchability, embryonic mortality and hatched chicks weight (Means \pm SE).

\begin{tabular}{|c|c|c|c|c|}
\hline Treatments & $\begin{array}{c}\text { Egg weight } \\
(\mathrm{gm})\end{array}$ & $\begin{array}{c}\text { Hatchability } \\
(\%)\end{array}$ & $\begin{array}{c}\text { Embryonic } \\
\text { mortality } \\
(\%)\end{array}$ & $\begin{array}{c}\text { Hatched } \\
\text { chicks weight } \\
(\mathrm{gm})\end{array}$ \\
\hline & 56.95 & 95.60 & 4.40 & 43.18 \\
$\mathrm{~T}_{1}$ & \pm 0.07 & \pm 1.66 & \pm 1.66 & \pm 0.43 \\
& $\mathrm{a}$ & $\mathrm{a}$ & $\mathrm{a}$ & $\mathrm{a}$ \\
\hline & 56.61 & 92.45 & 7.55 & 42.45 \\
$\mathrm{~T}_{2}$ & \pm 0.46 & \pm 1.09 & \pm 1.09 & \pm 0.13 \\
& $\mathrm{a}$ & $\mathrm{a}$ & $\mathrm{a}$ & $\mathrm{ab}$ \\
\hline & 57.60 & 93.08 & 6.92 & 41.98 \\
$\mathrm{~T}_{3}$ & \pm 0.66 & \pm 2.27 & \pm 2.27 & \pm 0.21 \\
& $\mathrm{a}$ & $\mathrm{a}$ & $\mathrm{a}$ & $\mathrm{b}$ \\
\hline
\end{tabular}

- Different letters in each column mean significant differences at $(\mathrm{P} \leq 0.05)$.

$-\mathrm{T}_{1}=$ Negative control group (non-injected eggs).

- $\mathrm{T}_{2}=$ Positive control group (eggs injected with deionized water, $0.2 \mathrm{ml}$ volume).

- $\mathrm{T}_{3}=\mathrm{KI}$ group (eggs injected with $2 \mathrm{mg}$ potassium iodide/egg, $0.2 \mathrm{ml}$ volume).

The results in Table 2 showed that the ovo-injection with potassium iodide significantly increased the hemoglobin and PCV\% in broiler chicks compared with control groups $\left(\mathrm{T}_{1}\right.$ and $\mathrm{T}_{2}$ ). Our results agreed with Ibrahim et al., (2015) and Hassaan et al., (2015), who mentioned that the addition of KI with 1.2, 2.4, 4.8 $\mathrm{mg} / \mathrm{kg}$ ration resulted in a significant improvement in hemoglobin and hematocrit.

Table (2): Effect of in-ovo injection of potassium iodide on PCV and $\mathrm{Hb}$ of broiler chicks on the day of hatching (Means $\pm \mathrm{SE}$ ).

\begin{tabular}{|c|c|c|}
\hline Treatments & $\begin{array}{c}\mathrm{PCV} \\
\%\end{array}$ & $\begin{array}{l}\mathrm{Hb} \\
\mathrm{g} / \mathrm{dl}\end{array}$ \\
\hline $\mathrm{T}_{1}$ & $\begin{array}{c}30.08 \\
\pm 0.75 \\
\mathrm{~b} \\
\end{array}$ & $\begin{array}{c}16.59 \\
\pm 0.28 \\
\mathrm{~b}\end{array}$ \\
\hline $\mathrm{T}_{2}$ & $\begin{array}{c}30.16 \\
\pm 0.47 \\
\mathrm{~b} \\
\end{array}$ & $\begin{array}{c}16.90 \\
\pm 0.17 \\
\mathrm{~b}\end{array}$ \\
\hline $\mathrm{T}_{3}$ & $\begin{array}{c}32.22 \\
\pm 0.47 \\
\mathrm{a}\end{array}$ & $\begin{array}{c}18.15 \\
\pm 0.28 \\
\mathrm{a}\end{array}$ \\
\hline
\end{tabular}

- Different letters in each column mean significant differences at $(\mathrm{P} \leq 0.05)$.

$-\mathrm{T}_{1}=$ Negative control group (non-injected eggs).

$-\mathrm{T}_{2}=$ Positive control group (eggs injected with deionized water, $0.2 \mathrm{ml}$ volume).

$-\mathrm{T}_{3}=\mathrm{KI}$ group (eggs injected with $2 \mathrm{mg}$ potassium iodide/egg, $0.2 \mathrm{ml}$ volume). 
These results may be due to the effect of KI on thyroid gland activity and the increase in thyroxine effects. Moreover, our results agree with Ali et al., (2017) who reported that the $\mathrm{Hb}$ and $\mathrm{PCV} \%$ increase by adding iodine to the ration.

Data of Table 3 showed a significant elevation in the lymphocyte \%, and on the contrary, the heterophils $\%$ and $\mathrm{H} / \mathrm{L}$ ratio significantly decreased with $\mathrm{KI}$ injection. These results corresponded with the findings of Ali et al., (2017), and with the findings of Abaza et al., (2003) who record a positive correlation between thyroxine levels and lymphocytes\%.

Thyroid hormones are involved in the regulation of carbohydrate, lipid and protein metabolism (Yen, 2011). There is little information about iodine consumption and its effect on broiler chicks physiological traits.

Table (3): Effect of in-ovo injection of potassium iodide on Differential Leukocyte Count of broiler chicks on the day of hatching (Means $\pm \mathrm{SE}$ ).

\begin{tabular}{|c|c|c|c|c|c|c|}
\hline Parameters & $\begin{array}{c}\text { Hetero- } \\
\text { phils } \\
\%\end{array}$ & $\begin{array}{c}\text { Eosino- } \\
\text { phils } \\
\%\end{array}$ & $\begin{array}{c}\text { Baso- } \\
\text { phils } \\
\%\end{array}$ & $\begin{array}{c}\text { Lympho- } \\
\text { cytes } \\
\%\end{array}$ & $\begin{array}{c}\text { Mono- } \\
\text { cytes } \\
\%\end{array}$ & $\begin{array}{c}\text { H/L } \\
\text { Ratio }\end{array}$ \\
\hline \multirow{3}{*}{$\mathrm{T}_{1}$} & 28.60 & 2.00 & 1.80 & 63.00 & 4.60 & 0.45 \\
& \pm 0.87 & \pm 0.32 & \pm 0.37 & \pm 0.71 & \pm 0.51 & \pm 0.02 \\
& $\mathrm{a}$ & $\mathrm{a}$ & $\mathrm{a}$ & $\mathrm{b}$ & $\mathrm{a}$ & $\mathrm{a}$ \\
\hline & 29.00 & 2.00 & 1.80 & 63.60 & 3.60 & 0.46 \\
$\mathrm{~T}_{2}$ & \pm 1.05 & \pm 0.32 & \pm 0.37 & \pm 0.68 & \pm 0.40 & \pm 0.02 \\
& $\mathrm{a}$ & $\mathrm{a}$ & $\mathrm{a}$ & $\mathrm{b}$ & $\mathrm{a}$ & $\mathrm{a}$ \\
\hline & 25.80 & 1.80 & 1.60 & 67.40 & 3.40 & 0.38 \\
$\mathrm{~T}_{3}$ & \pm 0.37 & \pm 0.37 & \pm 0.25 & \pm 0.81 & \pm 0.68 & \pm 0.01 \\
& $\mathrm{~b}$ & $\mathrm{a}$ & $\mathrm{a}$ & $\mathrm{a}$ & $\mathrm{a}$ & $\mathrm{b}$ \\
\hline
\end{tabular}

-Different letters in each column mean significant differences at $(\mathrm{P} \leq 0.05)$.

$-\mathrm{T}_{1}=$ Negative control group (non-injected eggs).

$-\mathrm{T}_{2}=$ Positive control group (eggs injected with deionized water, $0.2 \mathrm{ml}$ volume).

$-\mathrm{T}_{3}=\mathrm{KI}$ group (eggs injected with $2 \mathrm{mg}$ potassium iodide/egg, $0.2 \mathrm{ml}$ volume).

From the data in Table 4, results showed no significant effect of KI on glucose concentration as compared with control $(\mathrm{P} \leq 0.05)$, while the ovo-injection of potassium iodide ( $\mathrm{T}_{3}$ group) led to a significant decrease in the level of serum cholesterol and triglycerides of broiler chicks as compared with the control group $(\mathrm{P} \leq 0.05)$.

The results of this study were in agreement with the results of Soliman et al., (2018) who reported that the iodine had a clear effect on reducing total lipids in the blood, except HDL, as its level increased significantly. Also, our results agreed with Hassaan et al., (2015) and Ibrahim et al., (2015) when they gave potassium iodide and led to a significant decrease in the cholesterol and triglycerides in the blood. Our study did not agree with He et al., (2002) and Yalçin (2004) when they have fed iodine $(5-8 \mathrm{mg} / \mathrm{kg}$ feed $)$, and the cholesterol and triglycerides were not affected. 
Table (4): Effect of in-ovo injection of potassium iodide on some blood parameters of broiler chicks on the day of hatching (Means \pm SE).

\begin{tabular}{|c|c|c|c|c|c|c|c|}
\hline Parameters & $\begin{array}{c}\text { Glucose } \\
\mathrm{mg} / \mathrm{dl}\end{array}$ & $\begin{array}{l}\text { Chol- } \\
\text { esterol } \\
\mathrm{mg} / \mathrm{dl}\end{array}$ & $\begin{array}{c}\text { Tri- } \\
\text { glyceride } \\
\text { mg/dl }\end{array}$ & $\begin{array}{l}\text { Total } \\
\text { Protein } \\
\text { g /dl }\end{array}$ & $\begin{array}{l}\text { Albu- } \\
\min \\
\mathrm{g} / \mathrm{dl}\end{array}$ & $\begin{array}{l}\text { Glob- } \\
\text { ulin } \\
\text { g /dl }\end{array}$ & $\begin{array}{l}\text { Albumin } \\
/ \\
\text { Globulin }\end{array}$ \\
\hline $\mathrm{T}_{1}$ & $\begin{array}{c}180.84 \\
\pm 2.45 \\
\mathrm{a} \\
\end{array}$ & $\begin{array}{c}301.17 \\
\pm 6.68 \\
\mathrm{a}\end{array}$ & $\begin{array}{c}129.80 \\
\pm 7.82 \\
\mathrm{a}\end{array}$ & $\begin{array}{c}1.65 \\
\pm 0.09 \\
\mathrm{a}\end{array}$ & $\begin{array}{c}0.99 \\
\pm 0.04 \\
\mathrm{a}\end{array}$ & $\begin{array}{c}0.67 \\
\pm 0.08 \\
\mathrm{a}\end{array}$ & $\begin{array}{c}1.57 \\
\pm 0.23 \\
\mathrm{a}\end{array}$ \\
\hline $\mathrm{T}_{2}$ & $\begin{array}{c}169.06 \\
\pm 3.64 \\
\mathrm{a}\end{array}$ & $\begin{array}{c}287.98 \\
\pm 7.90 \\
\mathrm{ab}\end{array}$ & $\begin{array}{c}122.63 \\
\pm 5.76 \\
\mathrm{a}\end{array}$ & $\begin{array}{c}1.82 \\
\pm 0.04 \\
\mathrm{a}\end{array}$ & $\begin{array}{c}1.10 \\
\pm 0.04 \\
\mathrm{a}\end{array}$ & $\begin{array}{c}0.73 \\
\pm 0.04 \\
\mathrm{a}\end{array}$ & $\begin{array}{c}1.54 \\
\pm 0.12 \\
\mathrm{a}\end{array}$ \\
\hline $\mathrm{T}_{3}$ & $\begin{array}{c}173.92 \\
\pm 6.17 \\
\mathrm{a}\end{array}$ & $\begin{array}{c}246.97 \\
\pm 24.69 \\
\text { b }\end{array}$ & $\begin{array}{c}103.84 \\
\pm 1.67 \\
\mathrm{~b}\end{array}$ & $\begin{array}{c}1.74 \\
\pm 0.04 \\
\mathrm{a}\end{array}$ & $\begin{array}{c}1.04 \\
\pm 0.04 \\
\mathrm{a}\end{array}$ & $\begin{array}{c}0.70 \\
\pm 0.06 \\
\mathrm{a}\end{array}$ & $\begin{array}{c}1.55 \\
\pm 0.17 \\
\mathrm{a}\end{array}$ \\
\hline
\end{tabular}

-Different letters in each column mean significant differences at $(\mathrm{P} \leq 0.05)$.

$-\mathrm{T}_{1}=$ Negative control group (non-injected eggs).

$-\mathrm{T}_{2}=$ Positive control group (eggs injected with deionized water, $0.2 \mathrm{ml}$ volume).

$-\mathrm{T}_{3}=\mathrm{KI}$ group (eggs injected with $2 \mathrm{mg}$ potassium iodide/egg, $0.2 \mathrm{ml}$ volume).

The reduction of total lipids, especially cholesterol and triglycerides in the blood (Table 4) might be due to the effect of iodine which enhances thyroid gland function and its activity. The iodine deficiency may lead to insufficient production of thyroid hormones and vice-versa, which affects on lipid metabolism Zhao et al., (2011), as there is a positive relationship between the activity of the thyroid gland and its hormones and iodine intake (El-Wardany et al., 2011).

Słupczyńska et al., (2014) mentioned that thyroid hormones play an important role in regulating lipid metabolism. Furthermore, Mullur et al., (2014) mentioned that thyroid hormones stimulate lipid metabolism and activation of fatty acids oxidation and adipose tissue breakdown, as well as increase the ability of the liver to biliary excretion of cholesterol.

There was no significant difference in the level of total protein, albumin, globulin and albumin/globulin in the serum of hatched chicks of all study's groups (Table 4), and this is inconsistent with El-Bahr et al., (2017) and Ali et al., (2017) who mentioned that the addition of iodine had no significant effect on blood proteins levels, on the other hand, our results did not agree with Hassaan et al., (2015) possibly due to the difference in birds age when given iodine.

We note from Table 5 that the ovo-injection of potassium iodide at a dose of $2 \mathrm{mg} / \mathrm{egg}$ and deionized water injection $0.2 \mathrm{ml}$ resulted in a significant decrease $(\mathrm{P} \leq 0.05)$ in the level of triiodothyronine hormone in $\mathrm{T}_{3}$ and $\mathrm{T}_{2}$ groups compared with the control group $\left(\mathrm{T}_{1}\right)$, as well as there is a significant increase in the level of thyroxine hormone of $\mathrm{T}_{3}$ group compared with the control groups $\left(\mathrm{T}_{1}\right.$ and $\left.\mathrm{T}_{2}\right)$, and there was no significant difference in the level of TSH hormone between the study groups at $(\mathrm{P} \leq 0.05)$.

It is known that iodine plays an important role in the thyroid gland function, especially its response to the TSH hormone, and thus its deficiency reduces 
hormone secretion (Chung, 2014). Perhaps the iodine is the main regulator of thyroid function, and its deficiency leads to insufficient thyroid hormones production (Schultz, 2012).

Table (5): Effect of in-ovo injection of potassium iodide on serum $\mathrm{T}_{3}, \mathrm{~T}_{4}$ and TSH hormones of broiler chicks on the day of hatching (Means $\pm \mathrm{SE}$ ).

\begin{tabular}{|c|c|c|c|}
\hline Treatments & $\begin{array}{c}\mathrm{T}_{3} \\
\text { (Triiodothyronine) } \\
\mathrm{nmol} / \mathrm{l}\end{array}$ & $\begin{array}{c}\mathrm{T}_{4} \\
\text { (Thyroxine) } \\
\text { nmol/1 }\end{array}$ & $\begin{array}{c}\text { TSH } \\
\mu \mathrm{lU} / \mathrm{ml}\end{array}$ \\
\hline $\mathrm{T}_{1}$ & $\begin{array}{c}4.26 \\
\pm 0.14 \\
\mathrm{a}\end{array}$ & $\begin{array}{c}10.42 \\
\pm 1.17 \\
\mathrm{~b}\end{array}$ & $\begin{array}{l}0.150 \\
\pm 0.02 \\
\mathrm{a}\end{array}$ \\
\hline $\mathrm{T}_{2}$ & $\begin{array}{c}3.66 \\
\pm 0.22 \\
\mathrm{~b}\end{array}$ & $\begin{array}{c}9.97 \\
\pm 0.22 \\
\mathrm{~b}\end{array}$ & $\begin{array}{l}0.150 \\
\pm 0.03 \\
\mathrm{a}\end{array}$ \\
\hline $\mathrm{T}_{3}$ & $\begin{array}{c}2.20 \\
\pm 0.06 \\
\quad c\end{array}$ & $\begin{array}{c}17.22 \\
\pm 0.52 \\
\mathrm{a}\end{array}$ & $\begin{array}{l}0.103 \\
\pm 0.03 \\
\mathrm{a}\end{array}$ \\
\hline
\end{tabular}

-Different letters in each column mean significant differences at $(\mathrm{P} \leq 0.05)$.

$-\mathrm{T}_{1}=$ Negative control group (non-injected eggs).

$-\mathrm{T}_{2}=$ Positive control group (eggs injected with deionized water, $0.2 \mathrm{ml}$ volume).

$-\mathrm{T}_{3}=\mathrm{KI}$ group (eggs injected with $2 \mathrm{mg}$ potassium iodide/egg, $0.2 \mathrm{ml}$ volume).

\section{ACKNOWLEDGMENTS}

We would like to thank everyone who has supported us, beginning from the University of Mosul, College of Agriculture and Forestry, Kosar Company and Dr. Nidal Abdul-Ghani for their kind assistance for conducting this research.

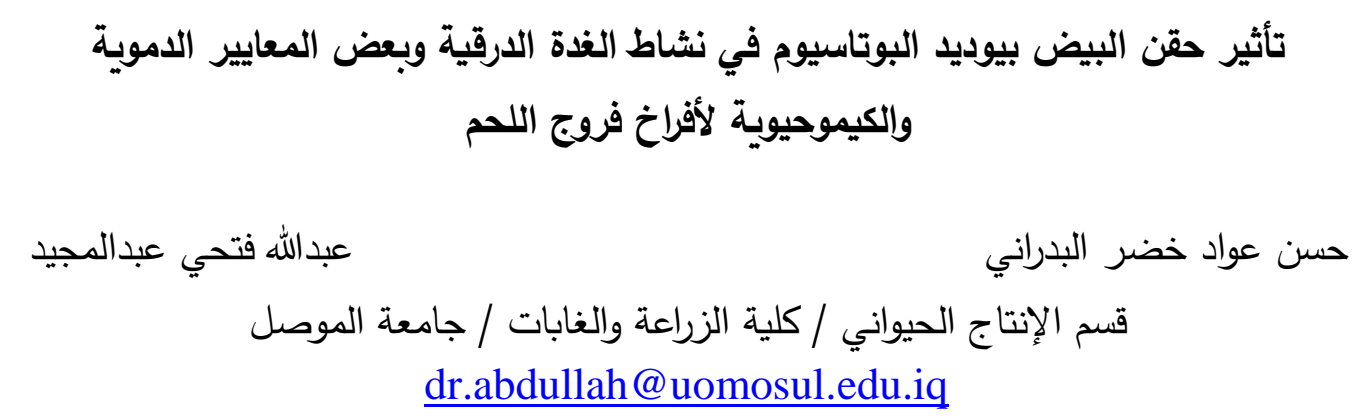

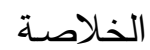

هدفت الدراسة الحالية إلى تقييم تأثيرات حقن البيض بيوديد البوتاسيوم في نشاط الغدة الدرقية وبعض المعايير الدموية والكيموحيوية لفروج اللحم. وزع عشوائياً 477 بيضة مخصبة لفروج اللحم (308 Ross) في 3 مجموعات (159 بيضة/مجموعة)، وبواقع 3 مكررات (53 بيضة /مكرر). بيض المجموعة الأولى 
اعتبر مجموعة سيطرة سالبة (غير محقون بأي مادة)، بيض المجموعة الثانية حقن بـ 0.2 مل من الماء منزوع الأيونات (مجموعة سيطرة موجبة)، وبيض المجموعة الثالثة حقن بـ 2 ملغم يوديد البوتاسيوم/ بيضة وبحجم 0.2 مل في الكيس الالنتويسي، وذلك في اليوم العاشر من الحضانة. في يوم الفقس، سجلت نسبة الفقس\% والهلاكات الجنينية\% ووزن الأفراخ الفاقسة، وأجريت الفحوصات الدموية والكيموحيوية. كان هناك انخفاض معنوي (أ205) في وزن الأفراخ الفاقسة في مجموعة يوديد البوتاسيوم مقارنة مع مجموعة السيطرة السالبة (أح0.05)، علاوة على ذلك، سجلت زيادة معنوية في كل من تركيز خضاب الدم وحجم خلايا الدم المرصوصة:\% والخلايا الليمفاوية\% وتركيز الثايروكسين مقارنة مع مجموعة السيطرة، وفي الوقت نفسه سجل انخفاض معنوي في الخلايا المتغايرة\% ونسبة الخلايا المتغايرة/الخلايا اللمفاوية والكولسترول والدهون الثلاثية وتركيز هرمون الثايرونين ثلاثي اليود (T3) مقارنة مع مجموعة السيطرة (أ20.05). نستتتج

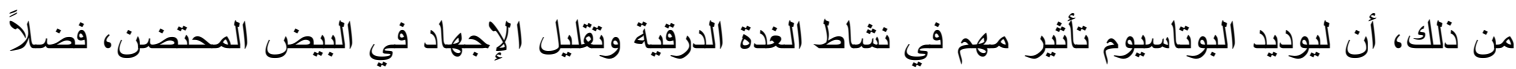
عن تأثيره في بعض المعايير الدموية للأفراخ الفاقسة. الكلمات الدالة: الحقن في البيض، يوديد البوتاسيوم، الغدة الدرقية، الثايروكسين، الثايرونين ثلاثي اليود. تاريخ تسلم البحث: 19 / 7 / 2020 ، وقبوله الله: 11 / 8 / 82020.

\section{REFERENCES}

Abaza, M., S.A. Elnagar; and A. El-Sebai (2003). Thyroid effects on semen quality and immune responses on mature Alexandria cockerels. Egyptian Poultry Science. 23(III); 721-736.

Ahmed, A.S., Jassim Q. Manati (2015). Effect of probiotics in ovo injection in some immunological, histological and microbiological characteristics of broiler chickens. Cihan University, First International Scientific conference.

Alhassani, D.H. (2000). Physiology of Domestic Fowl. $1^{\text {st }}$ Ed., Dar Alkutub for printing and publishing, Baghdad.

Ali, W.A.H., K.A. Ali, A.M. Hekal, F.M. Easa, M.A.A. EL-Aik and R.A. Ali (2017). Effect of Dietary Iodine Supplementation on Productive Performance of Pekin and Domyati Ducks during Growth Period. Journal of Animal and Poultry Production, 8(9), 381-389.

Anonymous (2008). Statistical Analysis Systems. Software, User's Guide: Statistics, V. 9.2, 2nd ed., SAS Institute, Cary, North Carolina, USA.

Behroozlak, M, M. Daneshyar and P. Farhomand (2020). The effects of dietary iodine and its consumption duration on performance, carcass characteristics, meat iodine, thyroid hormones and some blood indices in broiler chickens. Journal of Animal Physiology and Animal Nutrition, 104(3), 876885.

Bhanja, S.K., and A.B. Mandal (2005). Effect of in ovo injection of critical amino acids on pre-and post-hatch growth, immunocompetence and development of digestive organs in broiler chickens. Asian-australasian journal of animal sciences, 18(4), 524-531.

Bhanja, S.K., A.B. Mandal, S. Majumdar, M. Mehra and A. Goel (2012). Effect of in ovo injection of vitamins on the chick weight and post-hatch growth 
performance in broiler chickens. Indian Journal of Poultry Science, 47(3), 306-310.

Chung H.R. (2014). Iodine and thyroid function. Annals of pediatric endocrinology and metabolism, 19(1), 8-12. https://doi.org/10.6065/apem. $\underline{2014.19 .1 .8}$

Clauer, J. Phillip (2009). Incubating Eggs. Virginia Tech, PUBS 2902 - 1090. www.ext.vt.edu.

Duncan, D.B. (1955) Multiple range and multiple F-test. Biometric. 11: 1-42.

Eila, N., H. Asadi, M. Shivazad, A. Zarei, and N. Akbari (2012). Effect of different calcium iodate levels on performance, carcass traits and concentration of thyroid hormones in broiler chickens. Annals of Biological Research, 3(5), 2223-2227.

El-Bahr, S.M., A.A. Mandour and A. Hashem (2017). Effect of dietary supplementation of selected trace element or ascorbic acid on protein patterns of pre-immunized broiler chickens. Pharmacy and Pharmacology International Journal,5(1), 00110.

El-Wardany, I., E. F. El-Daly, A.H. Abd El-Gawad, A.E.A. Hemid and N.A. Abd El-Azeem (2011). Effect of thyroid activity modulation on some histological and biochemical aspects in broiler chicks. American-Eurasian Journal of Agricultural and Environmental Sciences, 11(6), 893-902.

Guo, Z., R. Narbaitz and J.N. Fryer (1991). Effects of excess iodine in chick embryo thyroid follicles: initial inhibition and subsequent hypertrophy. Journal of anatomy, 176, 157-167.

Hassaan, S.F., M.M Soliman and S.M. Osman (2015). Role of dietary iodine on modulating productive, reproductive, physiological and immunological performance in local chickens 1-during growth period. Egyptian Poultry Science Journal, 35(4): 991-1008.

He, M.L., W. Hollwich and W.A. Rambeck (2002). Supplementation of algae to the diet of pigs: a new possibility to improve the iodine content in the meat. Journal of Animal Physiology and Animal Nutrition, 86(3-4), 97-104.

Ibrahim, A.F., M.M. Beshara and H.S. Mohamed (2015). Effect of iodine supplementation to low energy diets on productive and reproductive performance in laying hens of local sinai strain. Journal of Animal and Poultry Production, 6(2), 99-135.

Kim, B. (2008). Thyroid hormone as a determinant of energy expenditure and the basal metabolic rate. Thyroid, 18(2), 141-144.

Klein, I., and K. Ojamaa (2001). Thyroid hormone and the cardiovascular system. New England Journal of Medicine,344(7), 501-509.

McNabb, F.A. (2006). Avian thyroid development and adaptive plasticity. General and comparative endocrinology, 147(2), 93-101.

Mullur, R., Y.Y. Liu and G.A. Brent (2014). Thyroid hormone regulation of metabolism. Physiological reviews, 94(2), 355-382.

Musa, M., F. Harun and S.M. Junit (2008). An investigation into the D727E polymorphism in the TSH receptor gene in patients with congenital hypothyroidism. Asia Pacific Journal of Molecular Biology and Biotechnology, 16(3), 65-69. 
Peebles, E.D. (2018). In ovo applications in poultry: A review. Poultry science, 97(7), 2322-2338.

Randall, M. and G. Bolla (2008). Raising Japanese Quail. Prime fact $602 / 2^{\text {nd }}$ Ed. https://www.dpi.nsw.gov.au/animals-and-livestock/poultry-and-birds/species/ Japanese-quail

Roto, S.M., Y.M. Kwon and S.C. Ricke (2016). Applications of in ovo technique for the optimal development of the gastrointestinal tract and the potential influence on the establishment of its microbiome in poultry. Frontiers in veterinary science, 3, 63.

Sainsbury, A., and L. Zhang (2012). Role of the hypothalamus in the neuroendocrine regulation of body weight and composition during energy deficit. Obesity reviews, 13(3), 234-257.

Saki, A.A., Farisar, M.A., Aliarabi, H., Zamani, P., and M. Abbasinezhad (2012). Iodine-enriched egg production in response to dietary iodine in laying hens. Journal of Agricultural Technology, 8(4), 1255-1267.

Schaal, T.P. (2008). The effect of in ovo feeding of fatty acids and antioxidants on broiler chicken hatchability and chick tissue lipids. Honors Bachelor of Science (HBS), Oregon State University.

Schmidt, R.E., and D.R. Reavill (2008). The avian thyroid gland. Veterinary Clinics of North America: Exotic Animal Practice, 11(1), 15-23.

Schultz, A.S. (2012). The Effect of Various Iodine Sources and Levels on The Performance and The Iodine Transfer in Poultry Products and Tissues (Doctoral dissertation), Tierärztliche Hochschule Hannover.

Słupczyńska, M., D. Jamroz, J. Orda and A. Wiliczkiewicz (2014). Effect of various sources and levels of iodine, as well as the kind of diet, on the performance of young laying hens, iodine accumulation in eggs, egg characteristics, and morphotic and biochemical indices in blood. Poultry science,93(10), 2536-2547.

Soliman, M.M., S.F. Hassaan, A. El-Halim and S. Osman (2018). Role of dietary iodine on modulating productive, reproductive, physiological and immunological performance for local chickens 2-during laying period. Egyptian Poultry Science Journal, 38(1), 91-101.

Steel, RGD. and JH. Torrie (1960). Principles and procedures of statistics: McGraw-Hill Book Company, Inc. New York Toronto London; 481 .

Yalçin, S., Z. Kahraman, S. Yalcin, S.S. Yalcin and H.E. Dedeoğlu (2004). Effects of supplementary iodine on the performance and egg traits of laying hens. British poultry science, 45(4), 499-503.

Yen, P.M. (2001). Physiological and molecular basis of thyroid hormone action. Physiological reviews, 81(3), 1097-1142.

Zhao, S.J., Y. Ye, F.J. Sun, E.J. Tian and Z.P. Chen (2011). The impact of dietary iodine intake on lipid metabolism in mice. Biological trace element research, 142(3), 581-588. 